\title{
Prevalence of anemia and iron deficiency in adolescent school girls of Dharan, Nepal
}

\author{
Nirmala Limbu', Dilip Thakur', Binod Kumar Lal Das², Lok Bandhu Choudhary³, \\ Anju Pradhan ${ }^{4}$, Dharanidhar Baral ${ }^{5}$ \\ ${ }^{1}$ Additional Professor, Department of Basic and Clinical Physiology, ${ }^{2}$ Assistant Professor, Department of Biochemistry, \\ ${ }^{4}$ Additional Professor, Department of Pathology, ${ }^{5}$ Assistant Professor, Department of Community Medicine, School \\ of Public Health \& Community Medicine, B.P. Koirala Institute of Health Sciences, Dharan, ${ }^{3}$ Lecturer, Department of \\ Physiology, Gandaki Medical College Teaching Hospital \& Research Centre, Lekhnath-Kaski, Nepal
}

\section{A B S T R A C T}

\begin{abstract}
Background: The prevalence of anemia in adolescence girls aresaid to be 42 to $60 \%$ in Nepal. Iron deficiency results from prolonged deficit of iron in diet or increased need for iron during a period of intense growth like adolescence. However, the terms anemia, iron deficiency, and iron deficiency anemia are used interchangeably. Aims and Objective: We aimed to find out the prevalence of anemia and iron deficiency in adolescent school girls of Dharan, Nepal by measuring hemoglobin and serum ferritin levels. Materials and Methods: This cross-sectional study was done in higher secondary schools, including government and private schools, of Dharan conducted by the Department of Basic and Clinical Physiology, B. P. Koirala Institute of Health Sciences, Dharan, Nepal. A total of 150 adolescent school girls of Dharanwas selected by systemic random sampling method. Hemoglobin and ferritin levels were analyzed by cyanmethemoglobinmethod andimmunoturbidimetric assay respectively. Descriptive statistics, paired t-test and chi-square test were used. Results: Anemic girls were $33.33 \%$ $(n=50 / 150)$. Anemia with iron deficiency was identified in $17.33 \%$ girls $(n=26 / 50)$ and anemia with normal iron level was in $16 \%$ girls $(n=24 / 50)$. Normal hemoglobin level with iron deficiency was identified in $9 \%(n=14 / 100)$ girls and normal hemoglobin with normal ferritin level was in $57 \%(n=86 / 100)$ girls.Conclusions: Prevalence of anemia was less in the adolescent school girls of Dharan, Nepal, than the earlier documented reports in which only half the anemic adolescent girls were iron deficient; suggesting that the remaining other anemic girls had other causes of anemia.
\end{abstract}

Key words: Anemia, Adolescent, Iron deficiency, Prevalence

\section{INTRODUCTION}

The prevalenceof anemia among adolescent girls' in Nepal is 42 to $60.0 \%{ }^{1-3}$ Iron deficiency anemia is severe form of iron deficiency.Presence of insufficient iron supply for the optimal physiological production and function of iron dependent cells is considered iron deficiency. ${ }^{4}$ Generally, it results from a prolonged deficit of iron in the diet or increasedneed for iron during a period of intense growthlike infancy, adolescence and pregnancy. ${ }^{5}$ Adolescence is a transition phase of life from childhood to adulthood. This phase of life is vulnerable to nutritional deficiency due to the increased nutritional demandsfor growth and development. ${ }^{6}$ In a developing country like Nepal,young girls are at high risk for the development of iron deficiency anemiabecause of gender discrimination and their socioeconomic status.

In the context of Nepal, most of the studies have identified iron deficiency anemia only based on hemoglobin level. The terms anemia, iron deficiency, and iron deficiency anemia are used interchangeably. The characteristics of iron deficiency anemia is not only low hemoglobin and hematocrit levels but also decreased iron store, low serum iron level anddecreased transferrin saturation. ${ }^{7}$ With the feasible resources, we aimed to study the prevalence of 
anemia and iron deficiency in adolescent school girls of Dharan, sub-metropolitan city, eastern part of Nepal by measuring hemoglobin and serum ferritin levels.

\section{MATERIALS AND METHODS}

This cross-sectional study was conducted in schools of Dharan from June 2014 to December 2014 after the ethical approval from the Institutional Review Committee. We did systematic random sampling method to select our subjects. There are 17 higher secondary schools in Dharan municipality. From these 17 schools, eight are government and nine are private higher secondary schools. From them, we had selected four schools, two government and two private schools, using population proportion sampling technique, which covered $25 \%$ of the total schools. After taking informed and written consent from the school principles of each four schools, we checked the registration list and got the total number of adolescent girls (11-19 years) studying in each school. Then, we selected $66 \%$ adolescent girls from the two government schools $(\mathrm{n}=100 / 1450)$ and $34 \%$ adolescent girls from the two private schools $(n=50 / 650)$. The objectives, procedure and benefits of the study were explained to the participating 150 adolescent girls to their satisfaction. Informed and written consent was also taken from their parents.

Height, weight and BMI of each selected girls were measured in their school. Their history was taken if they $\mathrm{had} /$ have any systemic diseases. Then, $5 \mathrm{ml}$ blood sample of these girls were collected from the cubital vein. It was placed into EDTA and heparinized tubes for hemoglobin and serum ferritin analysis respectively. Collected tubes were kept in a portable ice-box maintaining the temperature at $4{ }^{\circ} \mathrm{C}$. Then, it was sent to the biochemistry and pathology laboratories of B. P. Koirala Institute of Health Sciences, Dharan Nepal for their analysis. Hemoglobin was analyzed by cyanmethemoglobin methodand ferritin was analyzed by Tina-quant Ferritin Gen 3 Roche/Hitachi cobas c system which works on agglutination principle with enhancement of the reaction by latex.

We considered anemia when hemoglobin level was less than $12 \mathrm{~g} / \mathrm{dL}$ and depletion of iron stores when serum ferritin was less than $15 \mu \mathrm{g} / \mathrm{L}$ as per the WHO cut-off value. ${ }^{5}$ Likewise, we classified anemia as mild, moderate and severe when hemoglobin level was 11 to $11.9 \mathrm{gm} / \mathrm{dL}$, 8 to $10.9 \mathrm{~g} / \mathrm{dL}$ and less than $8 \mathrm{gm} / \mathrm{dl}$ respectively as per the WHO cut-off value. ${ }^{8}$ The result obtained was shared with the participants. Then, appropriate advice was given to those having hemoglobin and ferritin values below normal levels. Descriptive statistics was used to describe the frequency of hemoglobin and ferritin level; paired t test was used to compare the data showing normal distribution and Chi Square test was used to compare the categorical variables of anemic and non-anemic adolescent school girls. A p-value of $<0.05$ was considered statistically significant.

\section{RESULTS}

We had screened 150 adolescent school girls for anemia and iron store level. From these adolescent girls, $66.66 \%$ $(\mathrm{n}=100)$ and $33.3 \%(\mathrm{n}=50)$ girls were enrolled in our study from the two government schools and two private schools respectively (Table 1).

From the total 150 adolescent school girls, $33.33 \%(\mathrm{n}=50)$ girls were anemic and the remaining $66.67 \%(\mathrm{n}=100)$ girls were not anemic (Table 1). The frequency of anemia in the government and private sector higher secondary schools were similar $(\mathrm{p}=0.52)($ Table 2$)$.

The mean age (years), height $(\mathrm{m})$, weight $(\mathrm{kg})$ and BMI $\left(\mathrm{Kg} / \mathrm{m}^{2}\right)$ of total adolescent girls are shown in Table 3. These general characteristics of anemic and non-anemic adolescent girls were similar but there was a significant decrease of hemoglobin and ferritin levels in anemic girls compared to non-anemic girls $(\mathrm{Hb}$ level, anemic girls $=$ $11.10 \pm 0.92$ Vs. non-anemic girls $=12.90 \pm 0.68, \mathrm{p}=<0.001$; ferritin level, anemic girls $=21.85 \pm 17.80 \mathrm{Vs}$. non-anemic girls $=35.8 \pm 20.98 \mu \mathrm{g} / \mathrm{L}, \mathrm{p}=<0.001$ ) (Table 4).

From the 150 adolescent girls, $17.33 \%(n=26 / 150)$ girls were identified anemic with iron deficiency $(\mathrm{Hb}<12$ and ferritin $<15 \mu \mathrm{g} / \mathrm{L}), 16 \%(\mathrm{n}=24 / 150)$ girls were anemic with normal iron level $(\mathrm{Hb}<12$ and ferritin $>15 \mu \mathrm{g} / \mathrm{L})$, $9.33 \%(\mathrm{n}=14 / 150)$ girls were iron deficient without anemia $(\mathrm{Hb}>12$ and ferritin $<15 \mu \mathrm{g} / \mathrm{L})$ and $57.33 \%$ $(\mathrm{n}=86 / 150)$ girls were identified with normal hemoglobin and ferritin levels $(\mathrm{Hb}>12 \mathrm{gm} / \mathrm{dl}$ and ferritin $>15 \mu \mathrm{g} / \mathrm{L})$ (Table 5).

\begin{tabular}{llc}
\multicolumn{2}{l}{$\begin{array}{l}\text { Table 1: School distribution and screening of } \\
\text { anemia of adolescent girls, Dharan }\end{array}$} \\
\hline Characteristics & Categories & $\begin{array}{c}\text { Number of } \\
\text { adolescent } \\
\text { school girls (\%) }\end{array}$ \\
\hline $\begin{array}{l}\text { Higher } \\
\text { secondary } \\
\text { schools }\end{array}$ & Government school & $50(33.3)$ \\
& $\begin{array}{l}\text { Government school } \\
\text { Private school }\end{array}$ & $50(33.3)$ \\
Adolescent & Private school & $17(22.0)$ \\
school girls & Anemic & $50(33.33)$ \\
& Non-anemic & $100(66.67)$ \\
\hline
\end{tabular}




\begin{tabular}{|c|c|c|c|c|}
\hline \multirow[t]{2}{*}{ Characteristics } & \multirow[t]{2}{*}{ Category } & \multicolumn{2}{|c|}{ Adolescent school girls } & \multirow[t]{2}{*}{$p$ value } \\
\hline & & Anemic (\%) & Non-anemic (\%) & \\
\hline \multirow[t]{4}{*}{ Higher secondary schools } & Government school & $19(38.0)$ & $31(62.0)$ & 0.52 \\
\hline & Government school & $19(38.0)$ & $31(62.0)$ & \\
\hline & Private school & $8(24.2)$ & $25(72.7)$ & \\
\hline & Private school & $4(23.0)$ & $13(76.5)$ & \\
\hline Total & & $50(33.33)$ & $100(66.67)$ & \\
\hline
\end{tabular}

\begin{tabular}{|c|c|c|c|}
\hline Variables & Mean士SD & Minimum & Maximum \\
\hline Age (years) & $14.30 \pm 1.41$ & 11 & 18 \\
\hline Height $(m)$ & $1.53 \pm 0.06$ & 1.4 & 1.8 \\
\hline Weight (kg) & $46.22 \pm 7.82$ & 29 & 70 \\
\hline BMI $\left(\mathrm{kg} / \mathrm{m}^{2}\right)$ & $19.39 \pm 3.19$ & 13.77 & 29.51 \\
\hline
\end{tabular}

\begin{tabular}{|c|c|c|c|}
\hline Variables & Categories & Mean $\pm S D$ & $p$ value \\
\hline Age (years) & $\begin{array}{l}\text { Non-anemic }(n=100) \\
\text { Anemic }(n=50)\end{array}$ & $\begin{array}{l}14.41 \pm 1.39 \\
14.08 \pm 1.45\end{array}$ & 0.19 \\
\hline Height (m) & $\begin{array}{l}\text { Non-anemic }(n=100) \\
\text { Anemic }(n=50)\end{array}$ & $\begin{array}{c}1.534 \pm 0.07 \\
1.54 \pm 0.05\end{array}$ & 0.88 \\
\hline Weight (kg) & $\begin{array}{l}\text { Non-anemic }(n=100) \\
\text { Anemic }(n=50)\end{array}$ & $\begin{array}{l}45.82 \pm 7.82 \\
47.04 \pm 7.92\end{array}$ & 0.37 \\
\hline BMI $\left(\mathrm{kg} / \mathrm{m}^{2}\right)$ & $\begin{array}{l}\text { Non-Anemic }(n=100) \\
\text { Anemic }(n=50)\end{array}$ & $\begin{array}{l}19.44 \pm 2.93 \\
19.93 \pm 3.27\end{array}$ & 0.35 \\
\hline $\mathrm{Hb}(\mathrm{gm} / \mathrm{dL})$ & $\begin{array}{l}\text { Non-Anemic }(n=100) \\
\text { Anemic }(n=50)\end{array}$ & $\begin{array}{c}12.9 \pm 0.68 \\
11.10 \pm 0.92\end{array}$ & $<0.001$ \\
\hline Ferritin $(\mu \mathrm{g} / \mathrm{L})$ & $\begin{array}{l}\text { Non-Anemic }(n=100) \\
\text { Anemic }(n=50)\end{array}$ & $\begin{array}{l}35.80 \pm 20.98 \\
21.85 \pm 17.80\end{array}$ & $<0.001$ \\
\hline
\end{tabular}

\begin{tabular}{|c|c|c|c|c|c|c|}
\hline & \multicolumn{4}{|c|}{ Hemoglobin level } & \multirow{2}{*}{\multicolumn{2}{|c|}{ Total }} \\
\hline & \multicolumn{2}{|c|}{$\begin{array}{c}\text { Anemic } \\
(\mathrm{Hb}<12 \mathrm{gm} / \mathrm{dL})\end{array}$} & \multicolumn{2}{|c|}{$\begin{array}{c}\text { Non-Anemic } \\
(\mathrm{Hb}>12 \mathrm{gm} / \mathrm{dL})\end{array}$} & & \\
\hline & $\mathbf{n}$ & $(\%)$ & n & (\%) & $\mathbf{n}$ & (\%) \\
\hline \multicolumn{7}{|l|}{$\begin{array}{l}\text { Ferritin level } \\
(15-150 \mu \mathrm{g} / \mathrm{L})\end{array}$} \\
\hline $\begin{array}{l}\text { Decreased } \\
\text { iron store }\end{array}$ & 26 & 17.33 & 14 & 9.33 & 37 & 24.66 \\
\hline $\begin{array}{l}\text { Normal iron } \\
\text { store }\end{array}$ & 24 & 16 & 86 & 57.33 & 113 & 75.33 \\
\hline Total & 50 & 33.33 & 100 & 66.66 & 150 & 100 \\
\hline
\end{tabular}

From the 50 anemic adolescent school girls, $72 \%(n=36 / 50)$ had mild anemia $(\mathrm{Hb}=11-11.9 \mathrm{gm} / \mathrm{dl}), 26 \%(\mathrm{n}=13 / 50)$ had moderate anemia $(\mathrm{Hb}=8-10.9 \mathrm{gm} / \mathrm{dl})$ and $2 \%(\mathrm{n}=1 / 50)$ had severe anemia $(<8)$ (Table 6$)$.

In mild anemic adolescent girls, $32 \%(n=16 / 50)$ girls had decreased and $40 \%(n=20 / 50)$ girls had normal ferritin

\begin{tabular}{llc}
$\begin{array}{l}\text { Table 6: Severity of anemia of anemic } \\
\text { adolescent school girls, Dharan }\end{array}$ \\
\cline { 2 - 3 } Hemoglobin level & \multicolumn{2}{l}{ Anemic adolescent school girls } \\
\cline { 2 - 3 } & severity of anemia & $\mathbf{n}(\%)$ \\
\hline $11-11.9 \mathrm{gm} / \mathrm{dl}$ & Mild anemia & $36(72)$ \\
$8-10.9 \mathrm{gm} / \mathrm{dl}$ & Moderate anemia & $13(26)$ \\
$<8 \mathrm{gm} / \mathrm{dl}$ & Severe anemia & $1(2)$ \\
Total & & $50(100)$ \\
\hline
\end{tabular}

Table 7: Iron store level according to the severity of anemia of anemic adolescent school girls, Dharan

\begin{tabular}{|c|c|c|c|c|c|c|}
\hline & \multicolumn{4}{|c|}{$\begin{array}{c}\text { Ferritin } \\
\text { level }(15-150 \mu \mathrm{g} / \mathrm{L})\end{array}$} & \multirow{2}{*}{\multicolumn{2}{|c|}{ Total }} \\
\hline & \multicolumn{2}{|c|}{ Decreased } & \multicolumn{2}{|c|}{ Normal } & & \\
\hline & $\mathbf{n}$ & $(\%)$ & $\mathbf{n}$ & (\%) & $\mathbf{n}$ & (\%) \\
\hline $\begin{array}{l}\text { Severity of anemia* of anemic } \\
\text { adolescent girls }(\mathrm{Hb}, \mathrm{gm} / \mathrm{dL})\end{array}$ & & & & & & \\
\hline Mild & 16 & 32 & 20 & 40 & 36 & 72 \\
\hline Moderate & 9 & 18 & 4 & 8 & 13 & 26 \\
\hline Severe & 1 & 2 & - & - & 1 & 2 \\
\hline Total & 26 & 52 & 24 & 48 & 50 & 100 \\
\hline
\end{tabular}

*Hb level: Mild anemia $=11-11.9 \mathrm{gm} / \mathrm{dl}$, Moderate anemia $=8-10.9 \mathrm{gm} / \mathrm{dl}$, Severe $=<8$ $\mathrm{gm} / \mathrm{dl}$

level. In moderate adolescent anemic girls, $18 \%(\mathrm{n}=9 / 50)$ girls had decreased and $8 \%(\mathrm{n}=4 / 50)$ girls had normal ferritin level. In $2 \%(n=1 / 50)$ severe anemic adolescent girl had decreased ferritin level (Table 7).

\section{DISCUSSION}

We had investigated the prevalence of anemia and iron deficiency in adolescent local school girls of Dharan, Nepal. We found that the prevalence of anemia in this area of adolescent school girls was only $33.33 \%$ in which $72 \%$ had mild, $26 \%$ had moderate and $2 \%$ had severe anemia. Similar to ours, Gupta et al has reported the prevalence of anemia in adolescent girls of rural area of central Kathmandu is $35.3 \%{ }^{9}$ Other studies mostly done in various parts of eastern region of Nepal, however, have shown higher prevalence than ours: Sinha et al 56.3\% (retrospective hospital based study, Biratnagar), ${ }^{10}$ Baral and Onta 65.6\% (rural and urban area of Morang district). ${ }^{11}$ 
The possibility of this difference could be that we had studied in school-based population of Dharan while other had studied in different setting. The Survival for Women and Children (SWACH) Foundation study of India has demonstrated that prevalence of anemia is higher in nonschool going girls as compared to school going girls. This may be due to ignorance about the nutritional needs, as well as the socio-economic background of non-school going girls. ${ }^{12}$ Likewise, Kanodia et al had found the prevalence of adolescent girls of government school of Dharan was $51.3 \%$ which is more than our studies. ${ }^{13}$ We have studied in both the government and private higher secondary schools in contrast to Kanodia et al. We found no difference in the frequency of anemia in between these government and private schools. In private school girls, the possibility may not be due to poor socio-economic condition but due to body image, craze for trendy foods, peer influence, media and association of food with famous people have great influence in their nutritional status. ${ }^{12}$

Serum ferritin level reflects status of iron store in the body. We found that in mild anemic girls, 32\% had iron deficiency and $40 \%$ had normal iron store. In moderate anemic girls, $18 \%$ had iron deficiency and $8 \%$ had normal iron store. In $2 \%$ severe anemic girls had iron deficiency. Overall, 52\% girls had iron deficiency anemia and $48 \%$ anemic girls had normal iron store level. Study done by Chandya RK et al in women of reproductive age of Bhaktapur, Nepal, found that the prevalence of anemia and iron deficiency anemia was only $12 \%$ and $6 \%$ respectively. ${ }^{7}$ Similar to our finding in adolescent girls, they have reported anemia with normal iron store level in 47\% women of reproductive age. In this condition, they have found increased serum transferrin receptor level. The level of serum transferrin receptor reflects the intensity of red blood cell formationand the demand for iron. When the supply of iron to the tissues gradually declines, expression of transferrin receptor on the cell membrane increases. ${ }^{14}$ This hyperproliferative production of red blood cells may leads to other micronutrient deficiencies like folate, vitamin A and vitamin B12. ${ }^{15-17}$ Anemia with normal iron store level can be associated with infectious diseases like malaria, intestinal parasitic infestations and chronic infections. ${ }^{17}$

In non-anemic adolescent girls, we found that $9 \%$ girls had iron deficiency. This condition is called iron-deficient erythropoiesis, in which there is depleted iron stores and elevated transferrin receptor but normal hemoglobin level. ${ }^{7}$ It may be due to hyperproliferative erythropoiesis caused by other reasons or it may occur before iron stores are completely depleted. Both conditions lead to insufficient iron supply to the bone marrow. ${ }^{18,7}$
Ferritin is a better indicator for detecting iron deficiency when measuredin the absence of infection. ${ }^{8}$ Serum ferritin, along with soluble transferrin receptor, is a better indicator to measure the iron status of populations in areas where inflammation is not prevalent. ${ }^{19}$

Because of resource constraint, we have analyzed only serum ferritin level to assess the iron store level in adolescent girls. Most of the studies regarding the prevalence of iron deficiency anemia done in Nepal is based on the concentration of hemoglobin level only. Measuring only hemoglobin level as a proxy for iron deficiency and iron deficiency anemia underestimates other causes of anemia. $^{7}$

To conclude we found that the prevalence of anemia was less in the adolescent school girls of Dharan, Nepal, than the earlier documented reports, in which only half the anemic girls were iron deficient and remaining half had normal iron store level. Among anemia, prevalence of mild anemia was highest in which almost half of these anemic girls had iron deficient. This finding suggest that only half of these anemic girls had iron deficiency anemia and remaining other half could have other causes of anemia. It also gives indication that the terms anemia and irondeficiency anemia cannot be use interchangeably. Normal hemoglobin did not exclude iron deficiency as 9\% nonanemic girls had decreased ferritin level.

\section{ACKNOWLEDGEMENT}

We are thankful to the principle of schools, adolescent school girls and their parents who participated in our study. We acknowledge the financial support from the IndiaNepal BPKIHS Corpus Fund.

\section{REFERENCES}

1. Baral KP. Iron deficiency anemia: a public health nutrition problem in Nepal Implication in Policy and Program. J NepalPediatrSoc2003; 22: 29-41.

2. Kurz KM and Johnson-Welch $\mathrm{C}$. The nutrition and lives of adolescents in developing countries: findings from the nutrition of adolescent girls research program. ICRW, 1994.

3. Tiwari $\mathrm{K}$ and Seshadri S. The prevalence of anaemia and morbidity profile among school going adolescent girls of urban Kathmandu, Nepal. J NepAssoc 2000; 39: 319-325.

4. Ministry of Health and Population Nepal. Nepal Demographic and Health Survey 2006. New ERA Kathmandu and Macro International IncMaryland, 2007.

5. WHO/UNICEF/ICCIDD. Iron deficiency anaemia: assessment, prevention, and control, a guide for programme managers. Geneva, 2001.

6. Beard JL. Iron requirements in adolescent females. J Nutr 2000; 130 Suppl 2S: 440S-442S.

7. Chandyo RK, Strand TA, Ulvik RJ, Adhikari RK, Ulak M, Dixit H, 
et al. Prevalence of iron deficiency and anemia among healthy women of reproductive age in Bhaktapur, Nepal. European Journal of Clinical Nutrition 2007; 61: 262-269.

8. World Health Organization.Haemoglobin concentrations for the diagnosis of anaemia and assessment of severity. Geneva, 2011.

9. Gupta RK, Ghimire HP and Panta PP. Study of anemia in adolescents female and effect information, educationand communication in rural area of central Kathmandu Valley. Nepal Med Coll J 2013; 15(2): 129-132.

10. Sinha AK, Karki GMS Singh and Karna KK. Prevalence of Anemia amongst Adolescents in Biratnagar, Morang Dist. Nepal. International Journal of Pharmaceutical \& Biological Archives 2012; 3(5): 1077-1081.

11. Baral KP and Onta SR. Prevalence of anemia amongst adolescents in Nepal: a community based study in rural and urban areas of Morang District. Nepal Med Coll J 2009; 11(3): 179-182.

12. World Health Organization. Adolescent nutrition: A review of the situation in selected South-East Asian Countries. Regional office for South-East Asia New Delhi, 2006.

13. Kanodia P, Bhatta M, Singh RR, Bhatta NK and Shah GS. A study of anemia among adolescent girls in eastern part of Nepal. JCMS Nepal 2016; 12(1):19-22.
14. World Health Organization. Serum transferrin level for the assessment of iron status and iron deficiency in populations. Geneva, 2014.

15. Suharno D, West CE, Muhilal, Logman MH, de Waart FG, Karyadi $D$, et al. Cross-sectional study on the iron and vitamin A status of pregnant women in west Java, Indonesia. Am J ClinNutr 1992; 56 (6): 988-993.

16. Bondevik GT, Eskeland B, Ulvik RJ, Ulstein M, Lie RT, Schneede $\mathrm{J}$, et al. Anaemia in pregnancy: possible causes and risk factors in Nepali women. Eur J ClinNutr 2000; 54 (1): 3-8.

17. Dreyfuss ML, Stoltzfus RJ, Shreshtha JB, Pradhan KB, LeClerq SC, Khatry SK, et al. Hookworms, malaria and Vitamin A deficiency contributes to anaemia and iron deficiency among pregnant women in the plains of Nepal. J Nutr 2000; 130: 2527-2536

18. Hallberg L, Bengtsson C, Lapidus L, Lindstedt G, Lundberg P-A andHulten L. Screening for iron deficiency: an analysis based on bone-marrow examinations and serum ferritin determinations in a population sample of women. $\mathrm{Br} \mathrm{J}$ Haematol 1993; 85 (4): 787-798.

19. World Health Organization/Center for Disease Control and Prevention. Assessing the iron status of populations. Geneva, 2007.

\section{Authors Contribution:}

NL- Concept and design of the study, data collection, statistical analysis and interpretation, manuscript preparation, critical revision of the manuscript; DT- Design of the study, review of the study and helped in preparing first draft of the manuscript; BKLD- Design of the study, interpretation of the result and critical revision of the manuscript; LBC- Data collection, review of literature and helped in preparing first draft of manuscript; AP- Data collection and interpretation of the result; DB- Design of the study and statistical analysis.

Orcid ID:

Dr. Nirmala Limbu: (1) http://orcid.org/0000-0001-9100-8822

Dr. Dilip Thakur: (i) http://orcid.org/0000-0003-4183-5584

Dr. Binod Kumar Lal Das: (1) http://orcid.org/0000-0002-9550-2219

Mr. Lok Bandhu Choudhary: (D) http://orcid.org/0000-0002-1402-5247

Dr. Anju Pradhan: (D) http://orcid.org/0000-0002-7409-1940

Source of Support: None, Conflict of Interest: None declared. 